TECHNICAL TRANSACTIONS 11/2017

CZASOPISMO TECHNICZNE 11/2017

ENVIRONMENTAL ENGINERING

DOI: $10.4467 / 2353737$ XCT.17.195.7424

\author{
Anna Hajduk (anna.hajduk@uwm.edu.pl) \\ Marcin Dębowski \\ Marcin Zieliński \\ Paulina Rusanowska \\ Department of Environment Engineering, Faculty of Environmental Sciences, \\ University of Warmia and Mazury in Olsztyn
}

\title{
THE UTILISATION OF ZEOLITES FOR THE REDUCTION OF AMMONIUM CONCENTRATION IN BIOGAS PROCESSES
}

\author{
WYKORZYSTANIE ZEOLITÓW DO OGRANICZENIA STĘŻENIA AZOTU \\ AMONOWEGO PODCZAS PRODUKCJI BIOGAZU
}

\begin{abstract}
The aim of this study was to determine the impact of the utilisation of zeolites in the removal of ammonium from systems of biological the transformation of organic substrates to biogas during methane fermentation. The results showed that the highest efficiency of removal of ammonium from digestate was achieved with a $10 \mathrm{~g} / \mathrm{dm}^{3}$ dose of zeolite. This efficiency was from $37.87 \pm 0.54 \%$ to $46.01 \pm 0.8 \%$. The experiment demonstrated a linear relationship between the dose of zeolite in the range from $1 \mathrm{~g} / \mathrm{dm}^{3}$ to $10 \mathrm{~g} / \mathrm{dm}^{3}$ and the efficiency of the sorption and the final concentration of $\mathrm{N}_{-} \mathrm{NH}_{4}$. The highest sorption of $\mathrm{N}_{-} \mathrm{NH}_{4}$ was observed in a variant with the zeolite dose of $1 \mathrm{~g} / \mathrm{dm}^{3}$ and it was from $161.74 \pm 2.01 \mathrm{mg} \mathrm{N}-\mathrm{NH}_{4} / \mathrm{g}$ to $132 \pm 4.7 \mathrm{mg}$

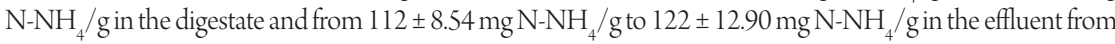
digestate.
\end{abstract}

Keywords: methane fermentation, nitrogen ammonium, zeolites, digestate, effluent from digestate

\section{Streszczenie}

Celem zrealizowanych prac badawczych było określenie wpływu zastosowania zeolitów w procesie usuwania azotu amonowego z systemów biologicznej transformacji substratów organicznych do biogazu w procesie fermentacji metanowej. Udowodniono, że najwyższą efektywność usuwania amoniaku z osadu beztlenowego uzyskano przy zastosowaniu dawki zeolitu wynoszącej $10 \mathrm{~g} / \mathrm{dm}^{3}$. Zawierała się ona w zakresie od 37,87 $\pm 0,54 \%$ do 46,01 $\pm 0,8 \%$. Eksperyment udowodnił liniową zależność między dawką

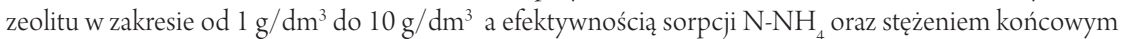
tego parametru. Największa jednostkowa ilość N-NH 4 sorbowana była w wariancie, w którym zastosowana dawka zeolitu wynosiła $1 \mathrm{~g} / \mathrm{dm}^{3}$. W odniesieniu do osadu pofermentacyjnego mieściła się w zakre-

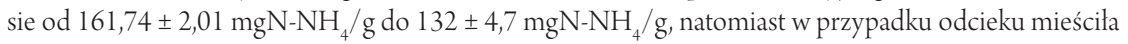
się w przedziale $112 \pm 8,54 \mathrm{mgN}_{-} \mathrm{NH}_{4} / \mathrm{g}$ do $122 \pm 12,90 \mathrm{mgN}^{-\mathrm{NH}_{4}} / \mathrm{g}$.

Slowa kluczowe: fermentacja metanowa, azot amonowy, zeolity, osad fermentacyjny, odciek z osadu fermentacyjnego 


\section{Introduction}

Methane fermentation is a biochemical process during which bacteria decompose organic matter and produce biogas [1]. This process can be disturbed or even hampered due to a variety of reasons. These include operator errors, technical problems, and the presence of inhibitors in substrates and biogas. The inhibitors, even in a low concentration, cause the incorrect operation of a biogas plant. The inhibitors can be delivered to a digester with a substrate or can be formed during the anaerobic fermentation inside a digester [2-4].

Ammonium is a nutrient for anaerobic bacteria, but its high concentrations inhibit fermentation. In digesters, ammonium occurs during the fermentation of nitrogen compounds such as urea and proteins [5]. Two forms of ammonium nitrogen can be distinguish. The first is the ionic form, ammonium ion $\mathrm{NH}_{4}{ }^{+}$, which is less toxic than the other form, ammonia $\mathrm{NH}_{3}$. During fermentation of livestock slurry and manure, considerable amounts of ammonium are produced - this adversely affects the development and activity of methanogenic microorganisms. Therefore, the presence of ammonium in the digester reduces the efficiency of methane production. It has been proven that ammonium concentrations in the range from

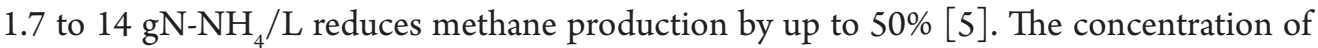
ammonium is influenced by the $\mathrm{pH}$ and the temperature of methane fermentation. Higher temperatures of the process accelerate metabolism and thus produce higher concentrations of ammonium.

Thus far, the removal of ammonium from digesters has been based on physicochemical and biological processes that do not always give satisfactory results; therefore, extensive studies on the use of natural zeolites (mainly clinoptilolite) for this purpose have been initiated. The removal of ammonium through the use of zeolite takes place by ion exchange or by adsorption in the pores of the aluminosilicate skeleton [6]. The introduction of zeolites into the fermentation chambers reduces the content of ammonium - this significantly limits the negative effect of this factor on anaerobic bacteria and directly affects the efficiency of biogas production. Such minerals placed in the fermentation chamber also bind other cations, including heavy metals, and enable efficient hydrogen sulphide binding, which directly promotes higher levels of biogas purity and higher methane content [1]. It seems that the efficiency of methane fermentation can be improved by using a suitable number of zeolites in the digesters.

One of the basic directions of development and use of digestate is its agricultural or natural use. Zeolites in digestate act as fertiliser carriers and after introduction into the soil, they enable the systematic and slow release of ammonium nitrogen [7]. This is a very desirable and important agrotechnical and ecological factor that protects the environment and crops from uncontrolled nutrient losses due to surface run-off and erosion. These phenomena have a negative impact both on crop yields and the accelerated eutrophication of surface water bodies.

This article presents the effect of a sorbent on the content of ammonium nitrogen, not only in the sludge supernatant (effluent from digestate) but also in the digestate. So complete studies are hard to find in other publications. It should be emphasised that although the mechanism of bonding of ammonium by zeolites is already known and has been repeatedly 
described, the use of such technology in biogas production systems is pioneering. According to the authors knowledge, this leads to a reduction in the concentration of ammonium, heavy metals and hydrogen sulphide in the fermentation chambers, which increases the efficiency of biogas production and improves its quality. The utilisation of zeolites also contributes to the development of fertilisers with modified properties that are justified both in agrotechnical and ecological terms. All the above aspects of zeolite application in biogas production systems will be developed in subsequent experimental work.

\section{Materials and methods}

\subsection{Organisation of the study}

In the experiment, the fermentation chambers were filled with sludge and plant biomass and different doses of zeolite. The study was divided into three series, depending of theplant biomass. Three plants were tested, in the 1 series - Helianthus tuberosus, in the 2 series Helianthus tuberosus, in the 3 series - Miscanthusgiganteus. In each series the different doses of zeolite were used. According to dose of zeolite, series were divided into variants. The following doses of zeolite were used: $0 \mathrm{~g} / \mathrm{L}$ ( 1 variant), $1 \mathrm{~g} / \mathrm{L}$ ( 2 variant), $5 \mathrm{~g} / \mathrm{L}$ (3 variant), $7.5 \mathrm{~g} / \mathrm{L}$ (4 variant), $10 \mathrm{~g} / \mathrm{L}$ (5 variant), $12.5 \mathrm{~g} / \mathrm{L}$ ( 6 variant). The studies focus on changes of ammonium concentration in digestate and effluent from digestate.

\subsection{Materials}

Fresh biomass was tested in the experiments. The biomass was obtained in November (week 46 of the year) from farmlands in Bałdy $\left(53^{\circ} 36^{\prime} 026^{\prime \prime} \mathrm{N}, 20^{\circ} 36^{\prime} 625^{\prime \prime} \mathrm{E}\right)$. The biomass was crushed to a $3 \mathrm{~mm}$ fraction in a knife mill. The process was carried out at a rotational speed of 2,800 rpm for 5 minutes. The specifications of the tested plant biomass are presented in Table 1.

Table 1. The specifications of the plant biomass

\begin{tabular}{|c|c|c|c|c|c|c|c|}
\hline \multirow{2}{*}{ Parameter } & \multirow{2}{*}{ Unit } & \multicolumn{2}{|c|}{ Helianthus tuberosus } & \multicolumn{2}{c|}{ Helianthus annuus L } & \multicolumn{2}{c|}{ Miscanthusgiganteus } \\
\cline { 3 - 8 } & & Amount & $\begin{array}{c}\text { Standard } \\
\text { deviation }\end{array}$ & Amount & $\begin{array}{c}\text { Standard } \\
\text { deviation }\end{array}$ & Amount & $\begin{array}{c}\text { Standard } \\
\text { deviation }\end{array}$ \\
\hline dry mass (d.m.) & {$[\mathrm{g}$ d.m./g] } & 0.4109 & 0.0021 & 0.3512 & 0.0029 & 0.3594 & 0.0012 \\
\hline mineral mass & {$[\mathrm{g} / \mathrm{g}$ d.m. $]$} & 0.0910 & 0.0021 & 0.0445 & 0.0022 & 0.0313 & 0.0018 \\
\hline $\begin{array}{c}\text { organic dry mass } \\
\text { (o.d.m.) }\end{array}$ & {$[\mathrm{g} / \mathrm{g}$ d.m. $]$} & 0.9090 & 0.0021 & 0.9555 & 0.0022 & 0.9687 & 0.0023 \\
\hline total nitrogen & {$[\mathrm{g} / \mathrm{g}$ d.m. $]$} & 0.643 & 0.09 & 0.661 & 0.11 & 0.364 & 0.04 \\
\hline ammonium & {$[\mathrm{g} / \mathrm{g}$ d.m. $]$} & 0.482 & 0.027 & 0.351 & 0.022 & 0.273 & 0.015 \\
\hline
\end{tabular}


The inoculum was anaerobic sludge obtained from digesters in a biogas plant in Łęguty $\left(53^{\circ} 45^{\prime} 16^{\prime \prime} \mathrm{N}, 20^{\circ} 09^{\prime} 52^{\prime \prime} \mathrm{E}\right)$ with corn silage and pig manure applied as substrates (OLR $3.2 \mathrm{~kg}$ o.d.m. $/ \mathrm{m}^{3} \mathrm{x} \mathrm{d}, \mathrm{HRT}-40 \mathrm{~d}$, temp $-42^{\circ} \mathrm{C}$ ). The specifications of the anaerobic sludge are presented in Table 2. The particle size of the clinoptilolite used in the experiments was 3-5 mm (Andalusia Sp z o.o.). The specifications of the zeolite used in the study are presented in Table 3.

Table 2. The specifications of the anaerobic sludge

\begin{tabular}{|c|c|c|c|}
\hline Parameter & Unit & Amount & Standard deviation \\
\hline dry mass (d.m.) & {$[\mathrm{g}$ d.m. $/ \mathrm{g}]$} & 0.044 & \\
\hline mineral mass & {$[\mathrm{g} / \mathrm{g} \mathrm{d} . \mathrm{m}]$.} & 0.386 & 0.00012 \\
\hline organic dry mass (o.d.m.) & {$[\mathrm{g} / \mathrm{g}$ d.m. $]$} & 0.614 & 0.0004 \\
\hline total nitrogen & {$[\mathrm{g} / \mathrm{g}$ d.m. $]$} & 0.387 & 0.078 \\
\hline ammonium & {$[\mathrm{g} / \mathrm{g}$ d.m. $]$} & 0.365 & 0.037 \\
\hline
\end{tabular}

Table 3. The specifications of zeolite (provided by the manufacturer)

\begin{tabular}{|c|c|c|}
\hline \multicolumn{3}{|c|}{ Chemical composition } \\
\hline Parameter & Unit & Amount \\
\hline $\mathrm{Na}_{2} \mathrm{O}$ & {$[\%]$} & 2.468 \\
\hline $\mathrm{Al}_{2} \mathrm{O}_{3}$ & [\%] & 14.431 \\
\hline $\mathrm{SiO}_{2}$ & [\%] & 74.620 \\
\hline $\mathrm{CaO}$ & [\%] & 2.186 \\
\hline $\mathrm{K}_{2} \mathrm{O}$ & {$[\%]$} & 2.870 \\
\hline $\mathrm{Fe}_{2} \mathrm{O}_{3}$ & [\%] & 2.030 \\
\hline $\mathrm{MgO}$ & [\%] & 0.850 \\
\hline others & {$[\%]$} & 0.545 \\
\hline \multicolumn{3}{|c|}{ Mineralogical composition } \\
\hline Parameter & Unit & Amount \\
\hline clinoptilolite & {$[\%]$} & 87 \\
\hline plagioclase & [\%] & 3 \\
\hline clay & [\%] & $3-4$ \\
\hline crystobalite & [\%] & 6 \\
\hline rutile & {$[\%]$} & $0.1-0.2$ \\
\hline
\end{tabular}




\subsection{Experimental setup}

The experiments were performed using the manometric OxiTop Control system. The manometric device consists of a $0.5 \mathrm{~L}$ glass bottle provided with and a pressure transducer located in a measuring head. In each of the variants of the experiment, $0.1 \mathrm{~L}$ of anaerobic sludge with the prepared lignocellulosic biomass and a dose of zeolite was introduced to the glass bottles. In all variants, initial organic loading was established at a level of $5.0 \mathrm{~g}$ o.d.m./L. In order to ensure anaerobic conditions within glass bottles, nitrogen was purged to replace the air present inside. A complete set of measurement was placed in a thermostatic cabinet with hysteresis that did not exceed $\pm 0.5^{\circ} \mathrm{C}$. Measurements were carried out at $36^{\circ} \mathrm{C}$. The duration of the experiment was 20 days.

\subsection{Analytical and statistical methods}

Analyses of the content of ammonium in the digestate and effluent from digestate were conducted. The effluent from the digestate was obtained through centrifugation. The concentration of the ammonium was determined by direct distillation (PN-EN 14671:2007). The dry organic matter and mineral matter in the sludge and biomass was determined with Polish Norm PN:EN 12880:2004. The total nitrogen content was determined through use of the Kiejdahl method. The measurements were performed after 20 days of methane fermentation.

The hypothesis on the distribution of each analysed variable was verified using the Shapiro-Wilk W test. The significance of the differences between the variables was stated with the use of a one-way analysis of variance (ANOVA). The homogeneity of variance in the groups was established using the Levene's test. The significance of differences between the analysed variables was determined with the RIR Tukey test. Differences were found to be significant at $\alpha=0.05$.

\section{Results and discussion}

The final $\mathrm{N}_{-} \mathrm{NH}_{4}$ concentrations in the digestate (6 variants) were $743 \pm 11.13 \mathrm{mg} / \mathrm{g}$ in Series $1,823 \pm 28.13 \mathrm{mg} / \mathrm{g}$ in Series 2 and $721.33 \pm 16.54 \mathrm{mg} / \mathrm{g}$ in the Series 3 (Fig. 1). The observed differences were statistically significant $(p \leq 0.05)$. The comparative efficiency of the removal of $\mathrm{N}_{-} \mathrm{NH}_{4}$ was noted in the effluent from digestate and depending on the series, the final concentrations of $\mathrm{N}_{-} \mathrm{NH}_{4}$ ranged from $674.8 \pm 20.89 \mathrm{mg} / \mathrm{g}$ to $809 \pm 21.54 \mathrm{mg} / \mathrm{g}$ (Fig. 2). Results of the experiments show a linear relationship between the dose of zeolite in the range from $1 \mathrm{~g} / \mathrm{dm}^{3}$ to $10 \mathrm{~g} / \mathrm{dm}^{3}$ and the final concentration of $\mathrm{N}_{-N_{4}}$ (Figs. 1-2). Further increases in the amount of zeolite introduced into the digesters no longer had a statistically significant

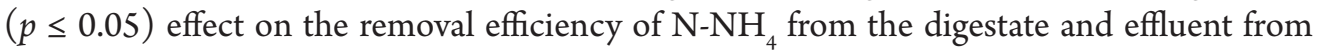
digestat. The efficiency of $\mathrm{N}_{-} \mathrm{NH}_{4}$ removal increased with increases in the doses of zeolite in both digestate and effluent from digestate. In digestate, the lowest $\mathrm{N}_{-} \mathrm{NH}_{4}$ sorption efficiency 
was $9.39 \pm 0.06 \%$ and it was noted in the first variant of Series 1 . The highest $\mathrm{N}^{-\mathrm{NH}_{4}}$ sorption efficiency was $48.66 \pm 0.19 \%$ and it was noted in the sixth variant of Series 3 (Fig. 3). The removal efficiency of $\mathrm{N}_{-} \mathrm{NH}_{4}$ from effluent from digestate ranged from $8.69 \pm 0.39 \%$ in the second variant of Series 2 to $49.8 \pm 1.41 \%$ in the sixth variant of Series 3 (Fig. 4).

It was noted that as the zeolite dose increased, the efficiency of the sorbent capacity reduced. The largest sorption of $\mathrm{N}_{-} \mathrm{NH}_{4}$ was in the second variant irrespective of the series (Figs. 5-6). Regarding the digestate, it ranged from $161.74 \pm 2.01 \mathrm{mg} \mathrm{N}-\mathrm{NH}_{4} / \mathrm{g}$ to $132 \pm$

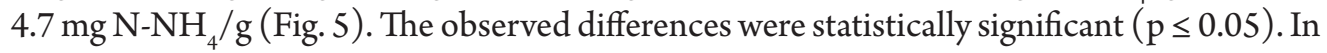
the case of effluent from digestate, the largest sorption of $\mathrm{N}_{-} \mathrm{NH}_{4}$ ranged from $112 \pm 8.54 \mathrm{mg}$ $\mathrm{N}^{-N_{4}} / \mathrm{g}$ to $122 \pm 12.90 \mathrm{mg} \mathrm{N}-\mathrm{NH}_{4} / \mathrm{g}$ (Fig. 6). The observed differences were statistically significant $(\mathrm{p} \leq 0.05)$.

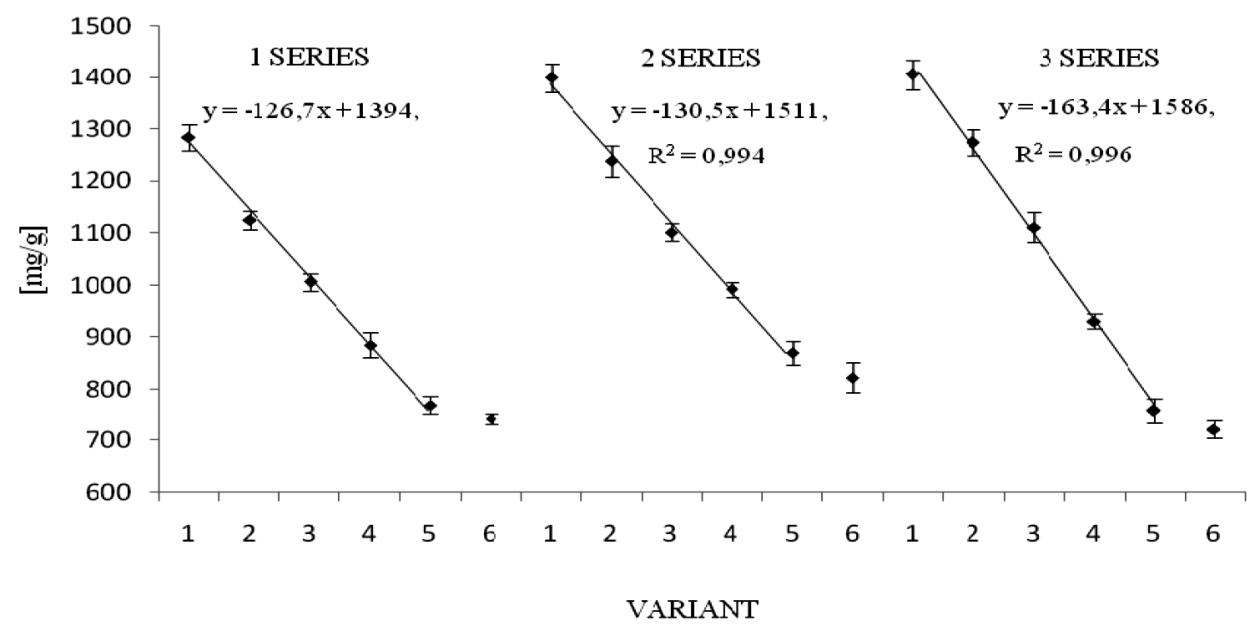

Fig. 1. The concentration of N-NH4 in digestate

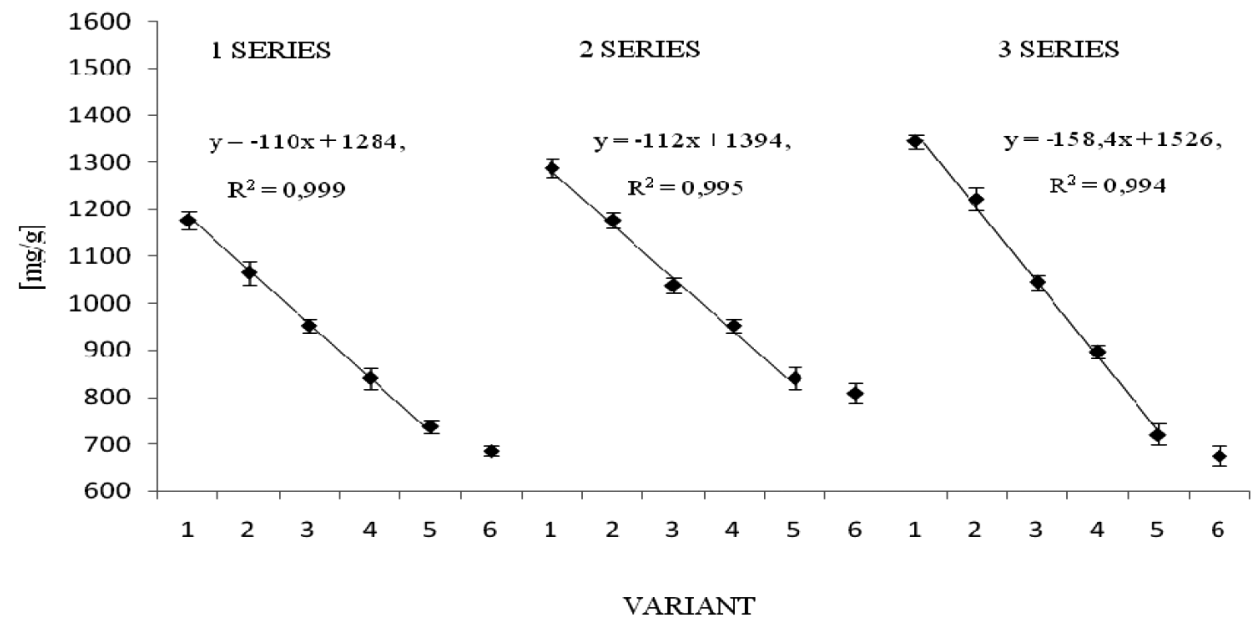

Fig. 2. The concentration of N-NH4 in effluent from digestate 


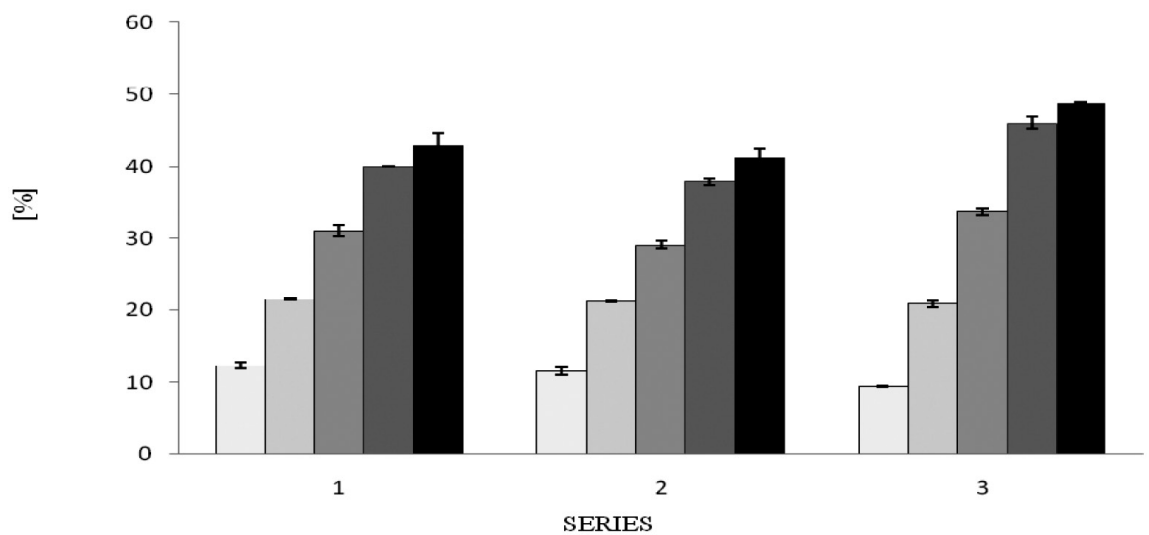

Fig. 3. The efficiency of N-NH4 removal in digestate

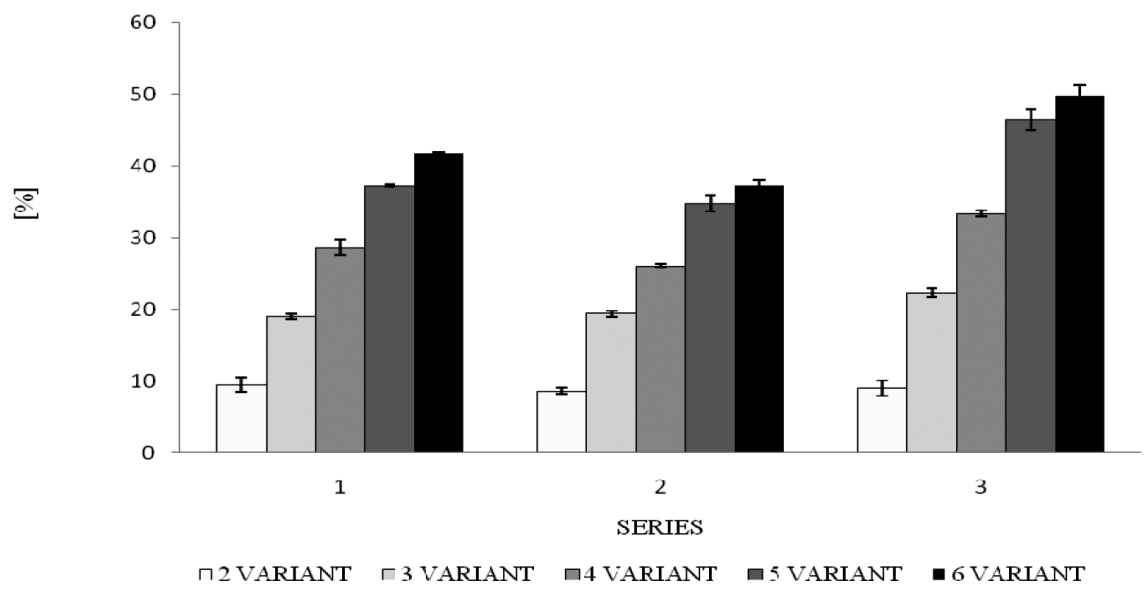

Fig. 4. The efficiency of N-NH4 removal in effluent from digestate

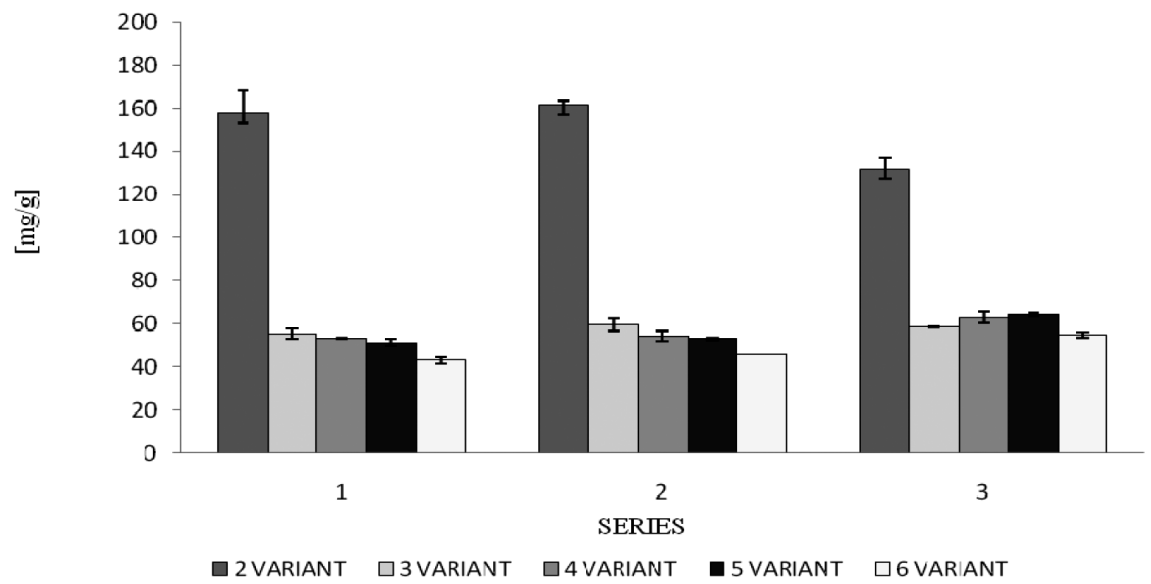

Fig. 5. The sorption of N-NH4 from digestate per gram of sorbent 


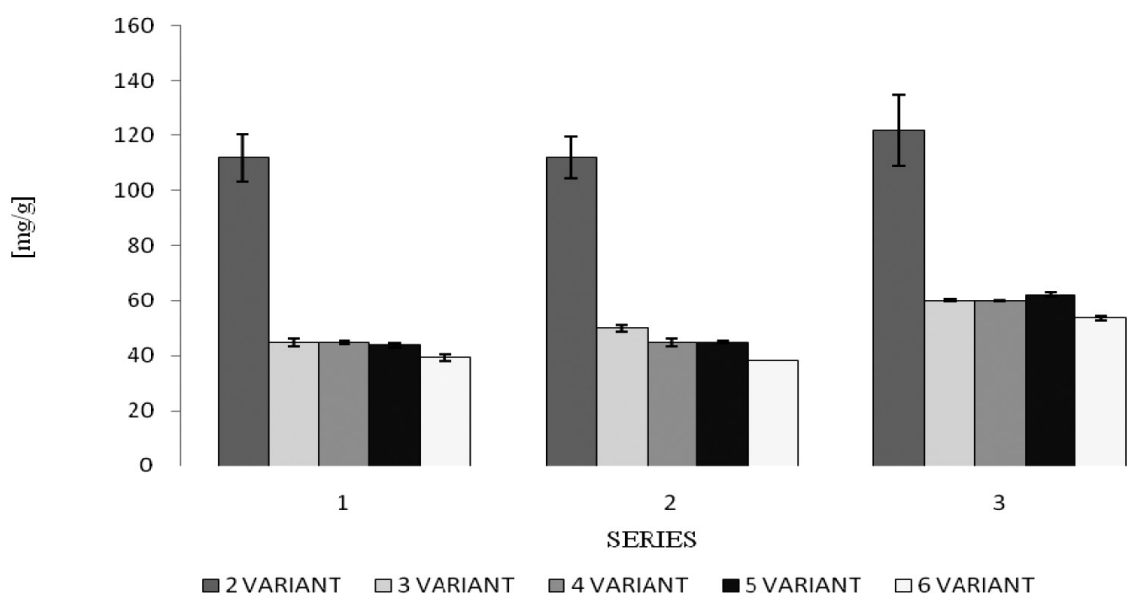

Fig. 6. The sorption of N-NH4 from digestate per gram of sorbent

Wiśniowska et al. (2015) performed a study regarding the use of zeolites for the removal of $\mathrm{N}^{-\mathrm{NH}_{4}}$ on a laboratory scale. The authors used a condensate from the high temperature drying of sewage sludge and sediment liquids mixed with synthetic municipal wastewater. As sorbents, the authors used horticultural zeolite and bentonite (in the form of commercially available cat litter). The authors proved that zeolite was more effective for ammonium

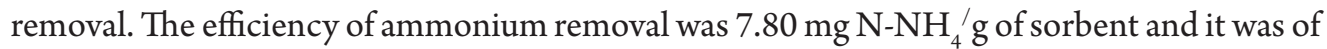
about $11 \%$ higher than the efficiency of ammonium removal with bentonite. These removal results are in the range obtained by other authors for natural zeolites, which were $0.4-25.5 \mathrm{mg}$ $\mathrm{N}-\mathrm{NH}_{4} / \mathrm{g}$ of sorbent [8-10]. In the present study, the obtained ammonium removal efficiency was much higher.

The digestate obtained after the anaerobic digestion of organic wastes has a nutrient content which is favourable for use as a crop fertiliser. The most cost-effective method for soil fertilising is direct application on the land. However, digestate is not easy to handle due to the fact that land fertilisation in appropriate periods needs a large storage capacity for digestate. Storage of digestate is expensive and the transportation of large volumes is ineffective from a logistical and economic point of view. However, the utilisation of zeolite material as a fertiliser requires the consideration of certain aspects. A total of $500 \mathrm{~kg}$ of clinoptilolite would be needed in a $50 \mathrm{~m}^{3}$ fermentation chamber to remove around $50 \%$ of the ammonium from digestate. In order to make the treatment process economically attractive, a greater increase in the concentration or a reduction in weight would be required; however, economy depends on both the cost of the ion exchanger/adsorbent and the transportation as well as the fertiliser properties regarding the nutrient bound to clinoptilolite, which may be more stable and easier to manage with regard to storage, distribution and application to soil [11].

Further removal of remaining ammonium might be removed in second-stage. Spreczyńska (2016) investigate removal $\mathrm{N}-\mathrm{NH}_{4}$ efficiency in a zeolite filled columns. The author removed $\mathrm{N}-\mathrm{NH}_{4}$ from reject water in columns with internal diameter of $3.4 \mathrm{~cm}$ filled with $436.7 \mathrm{~g}$ of zeolite. In the experiment, the author first identified the possibility of using natural zeolite to 
remove of ammonium from solutions with a filtering speed of $5.0 \mathrm{~m} / \mathrm{h}$. Than evaluated the effect of filtration velocity on the removal efficiency of ammonium from reject water. The experiments conducted by the author showed that the adsorption/ion exchange process on a zeolite-filled bed is an effective method of removing ammonium from aqueous solutions. The ammonium removal efficiency from model solutions, containing only ammonium chloride, was $80-90 \%$. This is in line with the literature. The ammonium removal efficiency from sludge supernatant was lower than in model solutions. The efficiency of ammonium removal dependent on the velocity of filtration through the zeolite bed. The efficiency of ammonium removal was $20-52 \%$ with filtration velocity $12.72 \mathrm{~m} / \mathrm{h}$. Threefold reduction of the filtration velocity lowered the efficiency of ammonium removal to $30-70 \%$. The lowering of the efficiency of ammonium removal was caused not only by filtration velocity but also composition of sludge supernatant (concentration of organics and fine suspension) [7].

\section{Conclusions}

The efficiency of $\mathrm{N}_{-} \mathrm{NH}_{4}$ removal increased linearly with increasing doses of zeolite (up to a dose of $10 \mathrm{~g} / \mathrm{dm}^{3}$ ) in the range from $9.39 \pm 0.09 \%$ to $48.66 \pm 0.19 \%$ in digestate and from $9.09 \pm 1.10 \%$ to $49.8 \pm 1.41 \%$ in effluent from digestate. Increasing the dose above $10 \mathrm{~g} / \mathrm{dm}^{3}$ did not improve the effect of ammonium removal. The highest sorption capacity was observed in the variant with a zeolite dose of $1 \mathrm{~g} / \mathrm{dm}^{3}$. In this variant, the sorption was $161.74 \pm 2.01 \mathrm{mg} / \mathrm{g}$ in the digestate and $122 \pm 12.90 \mathrm{mg} / \mathrm{g}$ in the effluent from digestate. There was no significant effect of the used plant biomass on the $\mathrm{N}_{-} \mathrm{NH}_{4}$ removal efficiency from the digestate and the effluent from the digestate.

\section{References}

[1] Pilarska A., Pilarski K., Krysztofiak A., Dach J., Witaszek K., Impact of additives on biogas efficiency of sewage sludge, Agricultural Eng. Vol. 3 (151), 2014, 139-148.

[2] Dinamarca S., Aroca G., Chamy R., Guerrero L., The influence of $\mathrm{pH}$ in the hydrolytic stage of anaerobic digestion of the organic fraction of urban solid waste, Water Sci. Technol. Vol. 48, 2003, 249-254.

[3] Ahring B.K., Perspectives for anaerobic digestion, Adv. Biochem. Eng. Biotechnol. Vol. 81, 2003, 1-30.

[4] Vavilin V.A., Fernandez B., Palatsi J., Flotats X., Hydrolysis kinetics in anaerobic degradation of particulate organic material: an overview, Waste Manage. Vol. 28, 2008, 939-951.

[5] Chen Y., Cheng J.J., Creamer K.S., Inhibition of anaerobic digestion process: a review, Bioresour. Technol. Vol. 99, 2008, 4044-4064.

[6] Baykal B.B., Guven D.A., Performance of clinoptilolite alone and in combination with sand filters for the removal of ammonia peaks from domestic wastewater, Water Sci Technol. Vol. 35(7), 1997, 47-54. 
[7] Spreczyńska E., Wykorzystanie zeolitu do usuwania jonów azotu amonowego z cieczy osadowej, Engineering and Protection of Environment Vol. 19(3), 2016, 391-399 (in Polish).

[8] Wiśniowska E., Karwowska B., Sperczyńska E., Interwencyjne wykorzystanie zeolitów w oczyszczaniu ścieków, Zeszyty Naukowe Inżynieria Środowiska Vol. 160(40), 2015, 56-63 (in Polish).

[9] Gupta V.K., Sadegh H., Yari M., Shahryari Ghoshekandi R., Maazinejad B., Chahardori M., Removal of ammonium ions from wastewater a short review in development of efficient methods, Global J. Environ. Sci. Manage. Vol. 1(2), 2015, 149-158.

[10] El-Shafey O., Fathy N.A., El-Nabarawy T., Sorption of ammonium ions onto natural and modified Egyptian kaolinites: kintic and equilibrium studies, Adv. Phys. Chem. Vol. 2014, 2014, 12.

[11] Kocatürk-Schumacher N.P., Bruun S., Zwart K., Jensen L.S., Nutrient recovery from the liquid fraction of digestate by clinoptilolite, Clean Soil Air Water Vol. 45(6), 2017, DOI: 10.1002/clen.201500153. 